the wastes of panic expenditure. Complete reserves for very exceptional droughts are unnecessary so long as they are adequate for other emergencies and plans are prepared for surmounting the difficulties of exceptional drought. Long views must be cultivated, since large water schemes take years to carry out. Where neighbouring areas have common interests, needs can best be met and expenditure saved by the formation of regional committees. Since water is so much a matter of local provision, and it is so important for democratic government to avoid excessive centralisation, water authorities must shed their parochialism and work out regional policies which, when dovetailed, will provide a national policy of the best sort, namely one fashioned from the needs of the areas which have to be served. If they do not co-operate in this way, compulsion may have to be applied. For rural supplies, help must be, and has been, provided. But rural consumers must pay their fair proportion towards the cost. If all parties do their share, the back of the rural problem can be broken with the million of money made available by the Government.

\section{Bacteriological Examination of Water}

IN a report recently issued by the Ministry of Health, a routine procedure is described for the bacteriological examination of water supplies (Reports on Public Health and Medical Subjects, No. 71. London : H.M. Stationery Office. 9d. net). Hitherto, almost every laboratory has employed its own technique, so that reports by different analysts on the same samples of water may show considerable variation and discrepancies. In a quantitative procedure like water analysis, it is especially important that all workers should employ the same methods, otherwise results, and the interpretation thereof, must vary from one laboratory to another. The procedure described in the present report, drawn up by an influential committee which included the late Sir Alexander Houston, if generally adopted, should go far to ensure more uniformity than formerly. The Committee, while describing in detail the general procedures, allows considerable latitude for the determination of the various indexes of excretal pollution. One of the principal innovations is the substitution of agar for gelatin medium for the count at $20^{\circ} \mathrm{C}$., and tables are provided by which the most probable numbers of $B$. coli in $100 \mathrm{ml}$. may be determined. Standards are suggested, and precise details are given for the taking of samples.

\section{Finds in the Kharga Oasis}

At the British Museum, exhibits from the Libyan Desert have been arranged at the head of the main staircase, primarily for the International Congress of Anthropological and Ethnological Sciences which is being held on July 30-Aug. 4, but the exhibition will remain open until the autumn. Under the auspices of the Royal Anthropological Institute, the expedition was conducted by Miss Caton-Thompson, the geological work being undertaken by Miss E. W. Gardner. The oasis is an area below the general level of the desert about 120 miles west of Thebes and 400 miles from the Mediterranean; and the most prolific sites on the floor of the Depression were fossil springs, which forced up sands and clays and formed mounds with the help of vegetation, such as palms and reeds. The mounds contain St. Acheul types of flint implements, with Aterian (Upper Palæolithic) after an interval. There is a general likeness to specimens from Palestine, and typical Levallois artifacts include several plunging flakes. The remarkable gloss, like porcelain, on many hand-axes is here accounted for by the friction of sand-charged water. On the scarp of the Depression Tufa deposits have yielded a number of flint implements ranging from St. Acheul to a phase preceding the Sebilian of the Nile Valley. The deposits include three species of fig, with land and freshwater shells all of living species. The rainfall can be studied from the combined evidence; and the exhibits include specimens of raw material roughly shaped, a fine series of arrow-heads from the surface, and contemporary beads of ostrich egg-shell. Finally, there is an object-lesson in patination, flints of a single culture showing at least three kinds of surface alteration.

\section{Panama Earthquake of July 18}

THE first movements of a great earthquake were recorded at Kew Observatory on July 18 at $1 \mathrm{~h} .48 \mathrm{~m}$. 29 s., G.M.T., the record indicating that the centre was at a distance of about 5,800 miles, probably in the Pacific Ocean off Ecuador. On the same day, a series of severe earthquakes occurred in the isthmus of Panama, one of which was strong enough to cause such damage in Ciudad David, in the extreme west of Panama, that it will have to be almost entirely rebuilt. No serious injury, it is said, occurred in the canal itself. From the first brief accounts, it would seem that the origin may be connected with that of the Colombia earthquake of January 31, 1906 (about 135 miles west of Esmeralda), possibly also with that of the Ecuador earthquake of last October 2 (NATURE, 132, 779, Nov. 18, 1933), though perhaps to the north or north-west of both.

\section{National Institute of Agricultural Botany}

AT the annual general meeting of fellows of the National Institute of Agricultural Botany at Cambridge on July 19, the chairman of the Council, Sir John Russell, in the course of his address stated that the year 1934 is one of the most important in the history of British agriculture for it is the year in which great schemes of organisation are being attempted. Gluts are good for no one, and it is far better to obtain supplies by definite organisation than by trusting to luck. For successful organisation, the best materials are essential, and the Institute, though not concerned with schemes for the organisation of marketing, is concerned with technical problems connected with improvement of agriculture. Its activities cover three broad fields. It helps the farmer by advising him as to the best varieties : it helps the scientific worker by telling him whether a new variety is worth marketing : and it helps the 